Gazi University
Journal of Science
$\mathrm{http} / /$ dergipark.gov.tr/gujs

\title{
Structures of Spermatheca and Eggs of the Red Firebug, Pyrrhocoris apterus (L. 1758) (Heteroptera: Pyrrhocoridae), Based on Optical and Scanning Electron Microscopy
}

\author{
Selami CANDAN ${ }^{(0)}$, Nurcan OZYURT KOCAKOGLU* \\ Gazi University, Faculty of Science, Department of Biology, 06500 Ankara, Turkey
}

\author{
Highlights \\ - Spermatheca and eggs of $P$. apterus were examined by the light and scanning electron microscopies. \\ - Newly laid eggs turn from white to yellow as soon as embryonic differentiation. \\ - The spermatheca of P. apterus consists of a bulb, a pump, a flange of pump, and duct.
}

\section{Article Info}

Received: 08 Mar 2021

Accepted: 09 July 2021

Keywords

Chorion

Micropyle

Spermathecal bulb

Electron microscope

Light microscope

\begin{abstract}
In this study, spermatheca and eggs of Pyrrhocoris apterus (Heteroptera: Pyrrhocoridae were examined by light microscope and SEM. The eggs have $\sim 1.30 \mathrm{~mm}$ length and $0.94 \mathrm{~mm}$ width. Newly laid eggs turn from white to yellow as soon as embryonic differentiation. P. apterus egg surface shows polygonal (usually hexagonal and pentagonal) shapes. The eggs have pipe shaped 6-7 micropylar projections. The egg-burster which is a dark T-shaped or triangular pattern, explosive becomes visible when the embryo is well developed. The nimph, which has completed its embryonic development, comes out of the egg with peristaltic movements. The spermatheca of $P$. apterus consists of a bulb, a pump, a flange of pump, and duct. The morphology of the egg and spermatheca is useful for classification, because they show a great diversity among species and genera.
\end{abstract}

\section{INTRODUCTION}

The firebug, Pyrrhocoris apterus (L., 1758) species Tilia spp. (Tiliaceae) feeding on the seeds of Malvaceae (s. Str.) and Robinia pseudacacia (Fabaceae), is a common and enterprising species found in the margins of Afrotropical and Eastern regions [1-4].

Although there are many studies on the morphology and surface structure of eggs of various Heteroptera species, many taxonomic groups still need research [5-24].

In insect, the spermatheca is in the form of differently shaped appendages of the female gonoduct, depending on the species. They serve to retrieve and store the spermatozoa transferred during mating and release egg cells for fertilization [25]. Spermatheca, whose structure is large and highly complex in Heteroptera, exhibits an important character for systematic, taxonomy and phylogeny [26]. This organ was mistakenly identified as the sebaceous gland in the first study of Hemiptera spermatheca in 1833 [27]. The correct description of a spermatheca (as receptaculum seminis) in Pentatomomorpha was made in 1837 [28]. Three major studies have been published on the structure of the female genitalia in Hemiptera [26,29,30]. Two very important studies were published in 1962 and 1966 on the male and female reproductive organs of Pentatomoidea [31,32]. 
In recent years, many studies have been conducted on the morphological studies of spermatheca belonging to different species of the order Heteroptera [17,18,33-49].

In this study, the egg structure and spermatheca morphology of $P$. apterus were examined and described in detail by light microscope and SEM.

\section{MATERIAL METHOD}

\subsection{The Eggs}

Adults of Pyrrhocoris apterus were collected from Safranbolu, Karabük (May 2018). Some of the fresh eggs obtained from the species kept under laboratory conditions were examined by Olympus SZX7 stereomicroscope and JEOL JSM 6060 LV scanning electron microscope (SEM) operated at 5-10 kV, 30 of them were measured and photographed.

\subsection{The Spermatheca}

For light microscope examinations, the spermatheca dissected from female were fixed in Bouin's fixative and then washed in 70\% alcohol and passed from $70 \%$ to $100 \%$ alcohol. After removing the excess of alcohol in xylol, they were embedded in paraffin wax. Sections cut at 6-7 $\mu \mathrm{m}$ were stained with hematoxylin-eosin (H\&E). The stained slides were photographed under BX51 Olympus light microscope.

Ten spermathecae were carefully removed from the abdomen softened in $10 \% \mathrm{KOH}$ for 5-10 minutes and then examined under a stereomicroscope (Olympus SZX7).

Spermatheca, cleaned with a graded alcohol series and air dried to be examined in SEM, was attached to the SEM stubs with double-sided tape and covered with gold (Polaron SC 502 Sputter Coater) and examined with SEM (Jeol JSM 6060 LV). Several terminologies have been used for Spermatheca [26,30,32,42].

\section{RESULTS AND DISCUSSION}

\subsection{Description of Eggs of Pyrrhocoris apterus}

The number of eggs laid varies among insect species. Each female in P. apterus, generally lays her eggs one by one in the environment (Figures 1a, b). Mecidea major Sailer, 1952 (Pentatomidae) female deposits total 10 eggs (double rows) on leaves [12]. The egg batches of Odontotarsus purpureolineatus (Rossi 1790) (Scutelleridae) generally consist of 13-14 eggs [17]. Eurygaster austriaca (Schrank, 1778) (Scutelleridae) egg mass generally consists of 14 eggs [18].

The shape and appearance of the egg differs from species to species. The oval-shaped eggs of $P$. apterus are $1.30 \mathrm{~mm}$ long and 0,94 $\mathrm{mm}$ wide on average (Figures 1a, 1b, 2a). In Euschistus obscurus (Palisot) (Pentatomidae), egg is subelliptical and length is 1.00-1.14 mm; diameter, 0.88-0.98 mm [11]. In Euschistus servus (Say) (Pentatomidae), egg is subelliptical and length is 0.98-1.18 mm; diameter, 0.86-1.10 mm [11]. In Euschistus tristigmus (Say) (Pentatomidae), the length of subelliptical shaped egg is 0.98-1.14 mm; diameter, 0.86-1.02 mm [11]. The egg of Piezodorus guildinii (Westwood) (Pentatomidae) is cylindrical and, 0.88-1.08 mm length; 0.58-0.80 mm diameter [11]. Thyanta custator accerra McAtee (Pentatomidae), egg is subcylindrical and 0.88-1.04 mm length; 0.76-0.88 mm diameter [11]. Eggs of O. purpureolineatus are about $1.35 \mathrm{~mm}$ long and $1.09 \mathrm{~mm}$ wide [17]. The eggs of E. austriaca are diameter of $1.05 \mathrm{~mm}$ [18]. The egg of Lethocerus delpontei (Belostomatidae) is 3-4 mm long, 2-2.5 mm wide, Kirkaldyia deyrolli (Vuillefroy, 1864) (Belostomatidae) egg is $4-5 \mathrm{~mm}$ length and 2.5-3 $\mathrm{mm}$ width [19]. In Chorosoma schillingi (Schilling, 1829) (Rhopalidae), the egg is 1.23 length and 0.56 width. The egg in Brachycarenus tigrinus (Schilling, 1829) (Rhopalidae) is 1.11 length and 0.37 width. Egg measurement of Rhopalus (Aeschyntelus) maculatus (Fieber, 1837) (Rhopalidae) is 1.0 length and 0.50 width [21]. The eggs of Brontocoris tabidus (Signoret, 1863) and Supputius cincticeps (Stål) (Pentatomidae) are subglobose to oval 
and have 2.8 and $2.05 \mathrm{~mm}$ height, 2.03 and $1.80 \mathrm{~mm}$ diameter [24]. The eggs of Podisus distinctus (Stål) (Pentatomidae) are $1.09 \mathrm{~mm}$ height and $0.90 \mathrm{~mm}$ diameter [45].

The color and patterning of eggs laid in the external environment vary widely among insect species. In $P$. apterus, newly laid eggs turn from white to yellow as soon as embryonic differentiation (Figures 1a-c). In Acrosternum hilare (Say) (Pentatomidae), egg color is lemon yellow or pea green [11]. Podisus maculiventris (Say) (Pentatomidae) egg color is pale yellow to metallic blue [11] While M. major eggs were white when they were first laid, they turned to cream color after 1-3 days [12]. The eggs of $O$. purpureolineatus are whitish when newly released, but turn into a light yellow color when embryonic development begins [17]. The newly laid eggs of E. austriaca are green, then the color slightly changed [18]. In $K$. deyrolli, the anterior half of egg is pale yellow and the dorsal side has 10-12 dark longitudinal stripes [19]. C. schillingi egg is brown after oviposition, darkening to brown to blackish. In B. tigrinus, the egg is green after oviposition, becoming dark green-brown. In $R$. maculatus, egg is goldish after oviposition, becoming yellow-brown to brown, due to embryo showing through [21]. The eggs of B. tabidus and $S$. cincticeps show a light or whitish appearance when first laid, and then turn into a graphite color [24]. The color of the newly laid eggs of $P$. distinctus is pearl-like, but four hours after oviposition, the eggs became gray [45].

As with other Pentatomidae, the first evidence of embryonic differentiation is the appearance of two contrasting red eye spots beneath the operculum $[11,18]$. Red eye spots and egg burster in the final stage of embryonic development are also seen in P. apterus (Figure 1c). In the final stage of embryonic development, nymphs emerge from the eggs (Figures 1d-f).

Egg surface appearance varies from species to species. The P. apterus egg surface shows polygonal (usually hexagonal and pentagonal) shapes (Figure 2e). The chorion of $A$. hilare is coarsely reticulate, foveate. The chorion of Nezara viridula (Linnaeus 1758) (Pentatomidae) and O. pugnax are nearly smooth. T. custator accerra has rough chorion [11]. Chorion surface of Cyrtocoris egeris Packauskas \& Schaefer (Pentatomidae) has smooth, lateral and superior surfaces with gross circular elevations. The $O$. purpureolineatus egg surface is covered by polygonal ridges and tiny chorionic tubercles [17]. The egg of E. austriaca is covered with a polygonal reticulated shape [18]. The chorion of L. delpontei, K. deyrolli, and Horvathinia pelocoroides Montadon, 1911 (Belostomatidae) is covered by a hexagonal pattern delimited by ridges in the three studied species [19]. Euschistus (Mitripus) convergens (Herrich-Schaffer), E. hansi Grazia, 1987, and E. picticornis Stål, 1872 (Pentatomidae) have spinose chorion surface. In Chinavia erythrocnemis (Berg), C. longicorialis (Breddin), C. obstinata (Stål, 1860), and C. pengue (Rolston, 1983) (Pentatomidae), egg surface is reticulated sculpture pattern and polygonal. The chorion of Chinavia musiva (Berg, 1878) (Pentatomidae) eggs shows a granulated sculpture pattern. Grazia tincta (Distant, 1890) (Pentatomidae) chorion pattern is sharply reticulated. Loxa deducta chorion surface is spinose. In Pallantia macunaim Grazia (Pentatomidae), chorion surface is covered by long and thin spines [20]. The chorion in C. schillingi is tetragonal and B. tigrinus has distinct low rounded tubercles [21].
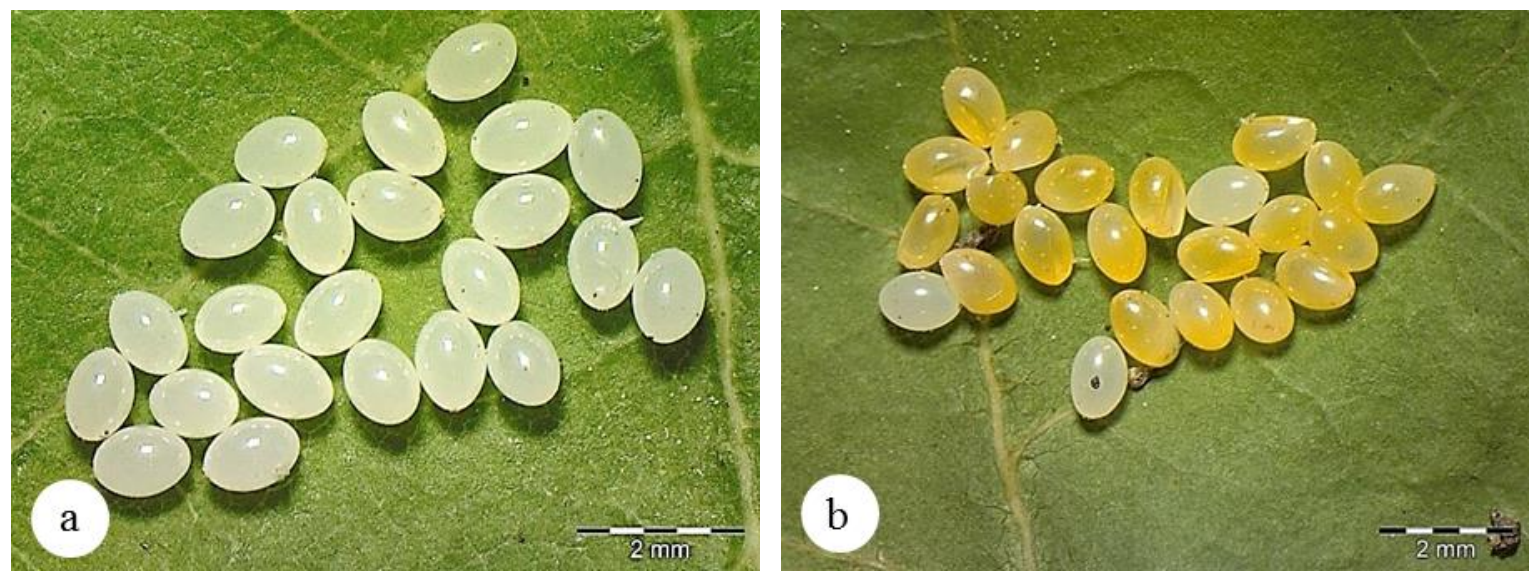

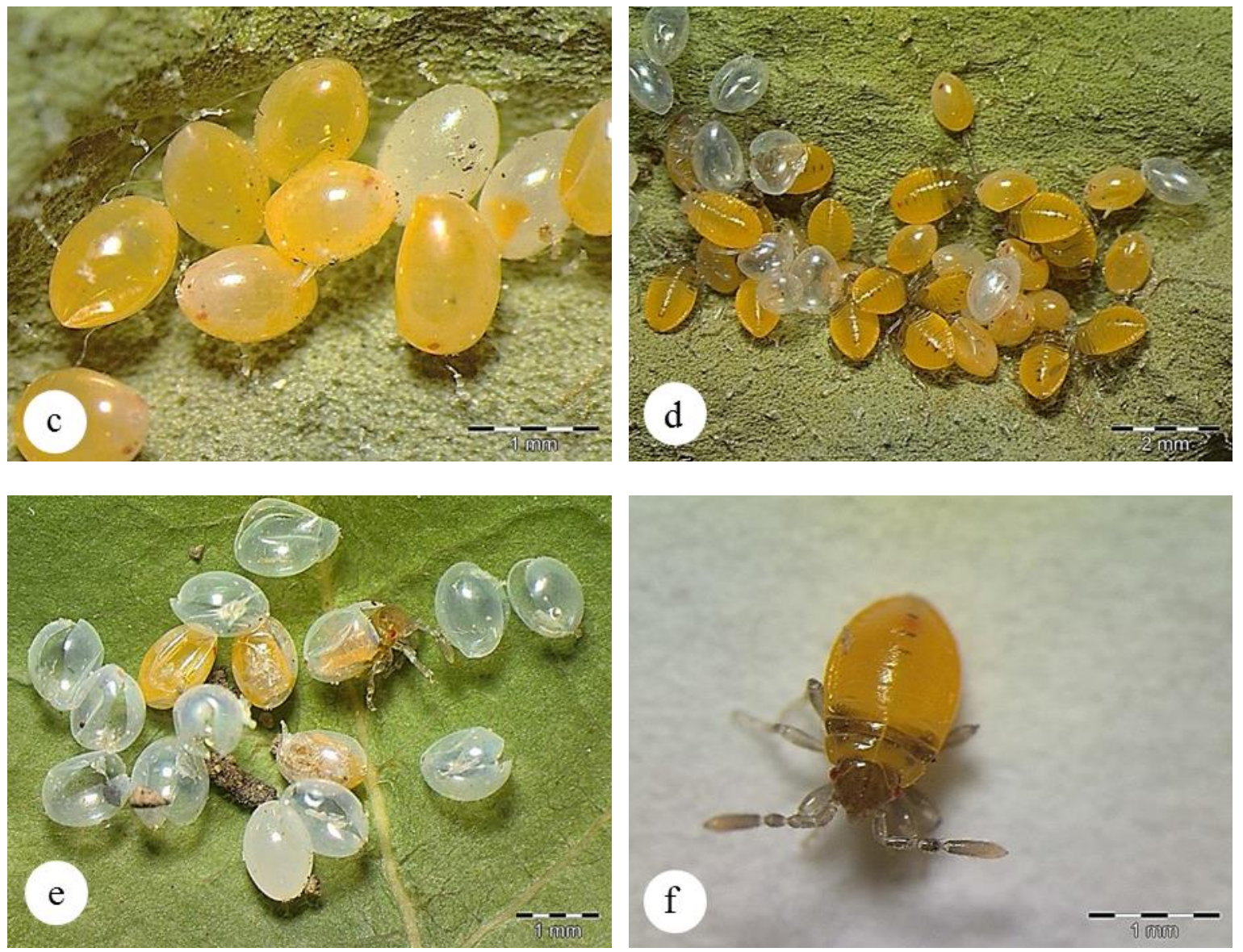

Figure 1. Light micrographs of different phases of eggs masses of P. apterus $a$. Newly laid egg mass. $b$. Embryonic development color change on the 3-4. day. c. The appearance of red eye spots. $d$-e. The emergence of nymphs from the egg in the final phase of embryonic development and the empty egg casings. $f$. The newly hatched nymph

The micropyles in P. apterus, which are responsible for the passage of sperm through the egg shell prior to fertilization, are located in the anterior region of the egg that are arranged in a circle, as in A. hilare egg [11]. The number and shape of micropiles vary in insect species. The micropyles in P. apterus have pipe shaped 6-7 micropylar projections. In P. apterus, the openings of all micropiles are facing out (Figures 2ad). T. custator accerra has clavate and slender shaped 18-25 micropylar processes [11]. In E. obscurus and E. servus, micropylar processes are 26-39 weakly clavate [11]. In Euschistus quadrator Rolston, 1874 (Pentatomide), micropylar processes are 29-39, weakly clavate. In E. tristigmus, micropylar processes are 28-39, weakly clavate [11]. P. guildinii has 31-44 micropylar processes [11]. In A. hilare egg, micropylar processes are 47-64, clavate and decurved [11]. O. pugnax is 50-79 mushroom-shaped micropylar processes [11]. As in A. hilare and P. guildinii, in P. apterus, micropyle surface is smooth. However, in E. obscurus, E. quadrator, E. servus, O. pugnax and E. tristigmus, the surface of micropyle is porous [11]. M. major egg is surrounded by 7-18 clavate and smooth micropylar processes [12]. In O. purpureolineatus egg has 8-10 aero-micropylar processes [17]. E. austriaca egg has 17-19 aeromicropyles which are truncated cone shapes [18]. In $K$. deyrolli and $L$. delpontei, there are 8 to 10 micropyles, arranged in an ellipsoid pattern [19]. $P$. distinctus, the aero-micropylar processes varied from 12 to 18 [45]. In C. obtusus eggs, the number of the micropylar processes varies from 18 to 19 [50]. T. marginata has 9-13 white aero-micropylar processes spaced, very long and slender [51].

The egg-burster begins to appear towards the end of embryogenesis (Figures $2 \mathrm{f}, 2 \mathrm{~h}$ ). Similar structures have been seen in E. austriaca [18]. In P. apterus, upon hatching, the pseudo-operculum is cracked through the middle of the micropiles by the egg-burster, which is thick and highly sclerotized (Figures $2 \mathrm{~g}, 2 \mathrm{~h}$ ). Similarly, C. obtusus eggs do not have real operculum and operculum hatching line. After the completion of embryonic egg development, it splits into two through the lateral hatching line with the help of the egg 
burster [50]. The egg-burster of $P$. apterus carries a dark T-shaped or triangular pattern (Figure $2 \mathrm{~h}$ ). The nimph, which has completed its embryonic development, comes out of the egg with peristaltic movements (Figures 1d-1f, 21, 2j). The egg-burster remains attached to the inner lateral face of the egg (Figure 2f).
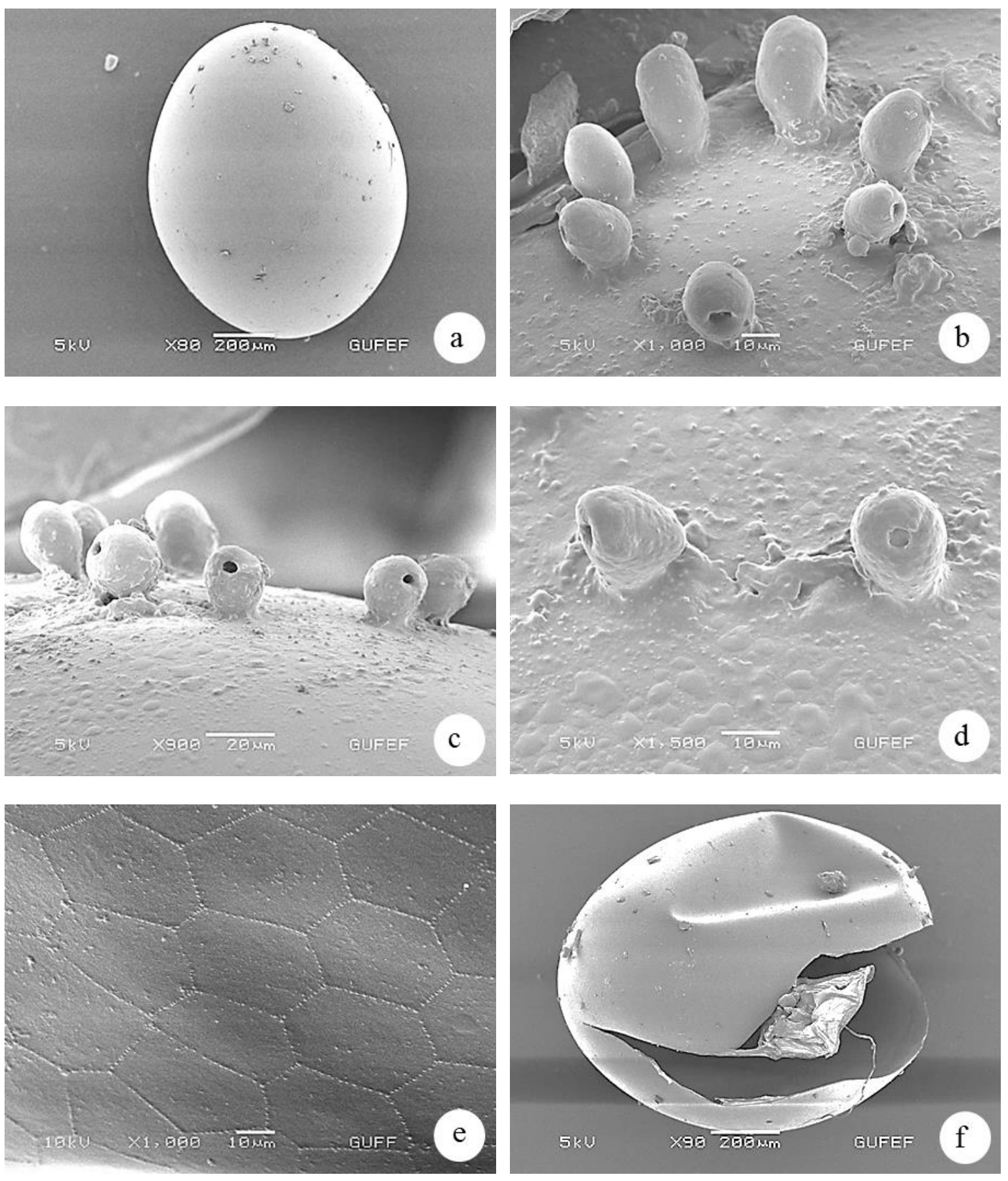

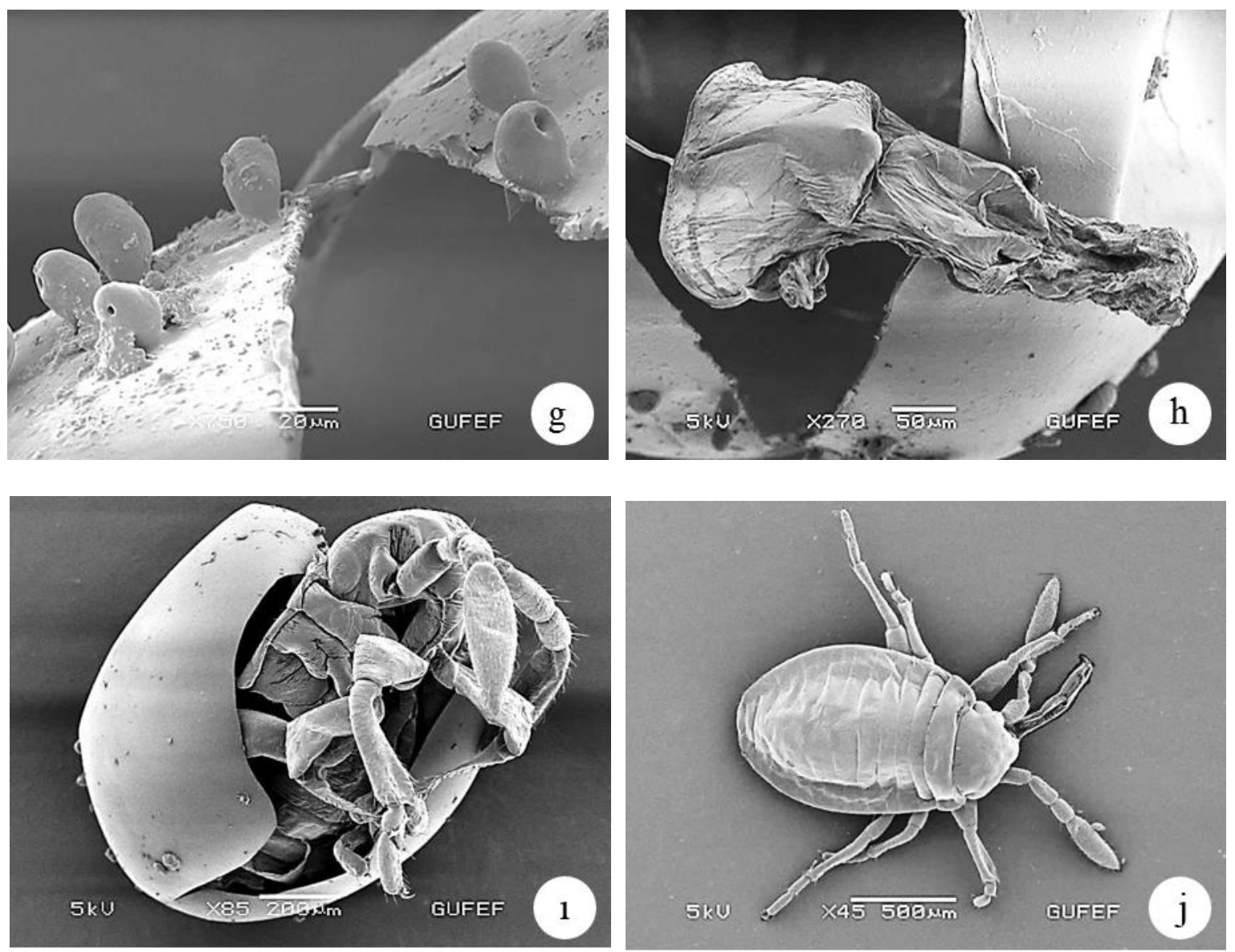

Figure 2. SEM micrographs of the eggs of Pyrrhocoris apterus. a. General view of the eggs of P. apterus, $b-d$. Micropyles and microplar opening. e. Polygonal with reticulated patterns on egg surface. $f$-g. Hatching line of egg and egg burster. h. The egg-burster on hatched eggs 1 . The emergence of nymph from the egg in the final phase of embryonic development. $j$. The newly hatched nymph

\subsection{Description of Spermatheca of Pyrrhocoris apterus}

The number and morphology of the spermatheca, an ectodermal organ responsible for receiving, protecting and releasing the sperm to fertilize the eggs in the female insect, varies according to the insect species [48].

In Heteroptera, spermatheca structure is different between families and even between species. The spermatheca of $P$. apterus consists of a bulb, a pump, a flange of pump, and duct. Spermathecal processes and a median spermathecal dilation with sclerotized rod are missing (Figures 3a-c). The spermatheca of $O$. purpureolineatus consists of a bulb, a pump, a flange, and dilation [17]. Spermatheca of Lygaeus simulans Deckert, 1985 (Lygaeidae) consists of the proximal part in convoluted tube shape and the distal part in irregularly coiled canal shape [37]. The spermatheca of E. austriaca, Rhaphigaster nebulosa (Poda 1761) (Pentatomidae), Palomena prasina (Linnaeus 1761) (Pentatomidae), Piezodorus lituratus (Fabricius 1794) (Pentatomidae), Graphosoma lineatum (Linnaeus 1758) (Pentatomidae), Graphosoma semipunctatum (Fabricius 1775) (Pentatomidae), Aelia albovittata (Fieber 1868) (Pentatomidae), Codophila varia (Fabricius 1787) (Pentatomidae), Ancyrosoma leucogrammes (Gmelin 1790) (Pentatomidae), Nezara viridula (Linnaeus 1758) (Pentatomidae) have a spermathecal bulb, a pumping region, distal and proximal flanges, and spermathecal ducts [18,39]. The spermatheca in Murgania histrionica (Hahn) (Pentatomidae) and Leptoglossus zonatus (Coreidae) consists of three main regions: the distal region, the median region and the proximal region [46,47]. The spermatheca consist of bulb and intermediate part which has distal, middle, and proximal regions [49].

The spermathecal bulb of $P$. apterus is spherical and sclerotized (Figures 3a, 3c), like in Thalma secunda (Dinidoridae), Dinidor rufocinctus Stål, 1870 (Dinidoridae), Byrsodepsus sundanus Breddin, 1900 
(Dinidoridae), O. purpureolineatus, Amnestus pusio (Stål, 1860) (Cydnidae), Pseudostibaropus testaceus (Walker, 1867) (Cydnidae), Cydnus aterrimus (Forster, 1771) (Cydnidae) and E. austriaca [17,18,41,42]. However, the bulb in Aradus australis Erichson (Aradidae) is flattened [34]. The spermathecal bulb of Eurydema oleraceum (Linnaeus, 1758) (Pentatomidae) and Eurydema ornatum (Linnaeus, 1758) (Pentatomidae) is semi-oblong [39]. The bulb in M. histrionica is a subcylindrical structure [48]. Coreus marginatus (Linnaeus, 1758) (Coreidae) has kidney-shaped bulb [49].

The diameter of the bulb in $P$. apterus is $218-278 \mu \mathrm{m}$. The bulb diameter of $O$. purpureolineatus is 280$310 \mu \mathrm{m} \mathrm{[17].} \mathrm{The} \mathrm{bulb} \mathrm{of} P$. apterus is surrounded by an inner cuticle (Figures 3e, 3f). A single layer epithelium lines a thick inner cuticle. External to the spermathecal epithelium, there are muscle fibers surround the entire spermathecal bulb (Figure $3 \mathrm{f}$ ). The bulb of $P$. apterus is covered by glandular cells. The glandular portion of the spermatheca in $P$. apterus consists of modified epithelial cells integrated into the reservoir wall. $P$. apterus has approximately 13-14 bulb glandular cells (Figure $3 \mathrm{f}$ ). In the bulb lumen, there are sperm bundles (Figure $3 \mathrm{f}$ ). The spermathecal bulb of $P$. apterus possesses many pores (Figure $3 \mathrm{~d}$ ), as $O$. purpureolineatus and E. ornatum [17,39]. However, in E. oleraceum, pores on the spermathecal bulb shows on the bulb anterior [39].

In $P$. apterus, the distal $(132 \mu \mathrm{m})$ and proximal flange $(154 \mu \mathrm{m})$ of the spermathecal pump are sclerotized and distal flange adheres closely to the bulb (Figure $3 \mathrm{~g}$ ) as in C. bechynei [41]. Nonetheless, distal flange is not adhering to the bulb in T. secunda, and in Colpoproctus pullus (Stål, 1853) (Dinidoridae), flanges are distant from the bulb [41]. In P. apterus, the proximal flange is larger than the distal one, as in T. secunda and $D$. rufocinctus [41]. However, in $M$. histrionica, the distal flange $(255 \mu \mathrm{m})$ is larger than the proximal one $(175 \mu \mathrm{m})$ [46], as in Isodermus tenuicornis Usinger and Matsuda (Aradidae), B. sundanus and Eurydema spectabilis Horváth, 1882 (Pentatomidae) [34,39,41]. In Doesbergiana borneoensis (Dinidoridae), distal and proximal flanges are equal in size [41]. The pumping region in P. apterus is short and between distal and proximal flange (Figure 3g). The pumping region is about $50.8 \mu \mathrm{m}$ long. Histologically, the wall of pumping region is surrounded by cuticle and a single layer cylindirical epithelium. In the lumen, sperm bundles are seen (Figure 3h).

The spermathecal duct of $P$. apterus is thin, long and has pores (Figures 31,3j). However, the spermathecal canals of $O$. purpureolineatus has distal, median and proximal portions. The first and third is narrow, second is swollen [17]. In Carventaptera spinifera U. \& M. (Aradidae), the duct is fairly short, narrow, and with slight basal swelling [34]. The spermathecal duct is responsible for sperm transfer from the spermatheca directly to the common oviduct [44].

More studies on eggs and spermatheca are needed to establish clear trends within the Pyrrhocoridae family. With this study, the morphological characters of the egg and spermatheca of P. apterus were defined and contributed to the higher classification of Pyrrhocoridae families.
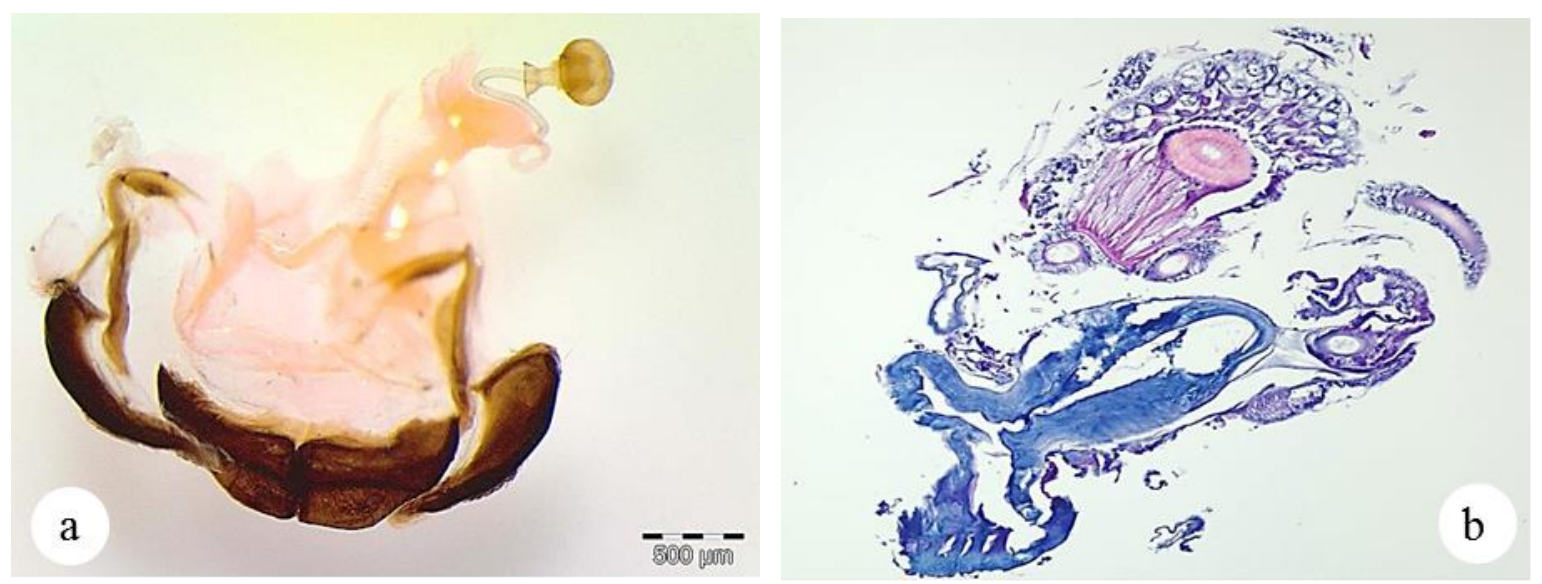

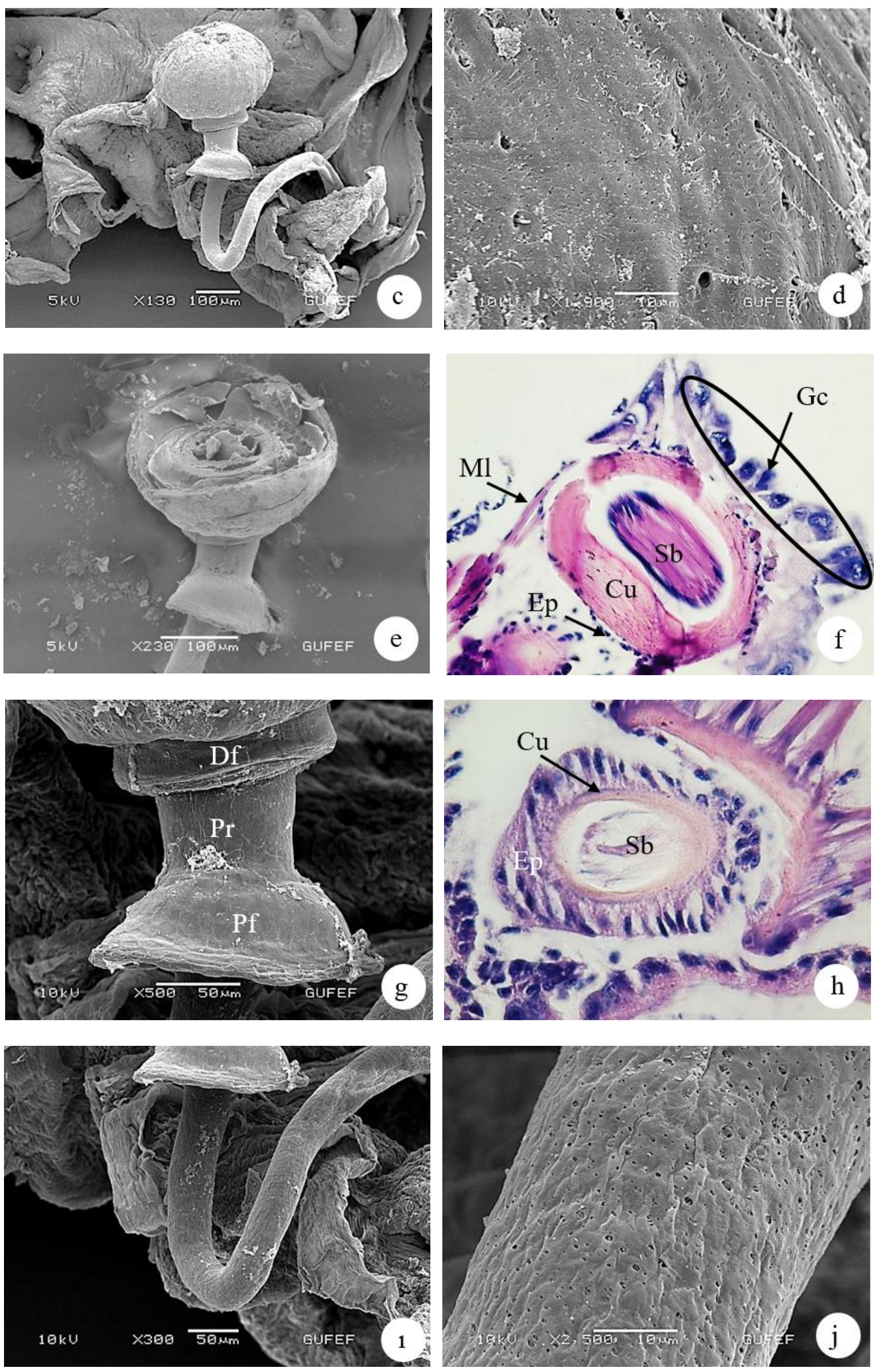
Figure 3. Light microscope and SEM micrographs of spermatheca. a. General view of spermathecal. $b$. The longitudinal section of spermathecal bulb $(X 40)(H \& E)$. c. Spermathecal bulb, distal and proximal flange and spermathecal duct. $d$. Pores on the spermathecal bulb surface. e-f. The cross section of the spermathecal bulb $(X 400)(H \& E)$. g. The pumping region between distal and proximal flanges. $h$. The cross sections of pumping region. $1, j$. Spermathecal duct and pores in spermathecal duct surface. Abbreviations: Gc-glandular cell, Sb-sperm bundle, Cu-cuticle, Ep-epithelium, Ml-muscle layer, Df-distal flange, Pr-pumping region, Pf-proximal flange

\section{CONFLICTS OF INTEREST}

No conflict of interest was declared by the authors.

\section{REFERENCES}

[1] Massee, A.M., "In search of Pyrrhocoris apterus (L.) (Hem., Pyrhocoridae) in devonshire", Entomologist's Monthly Magazine, 90: 45-46, (1954).

[2] Henry, T.J., "Family Pyrrhocoridae Fieber, 1860”, In T.J. Henry, R.C. Froeschner (Editors). Catalogue of the Heteroptera, or True Bugs, of Canada and the Continental United States, 613616, (1988).

[3] Kerzhner, I.M., "Family Pyrrhocoridae Amyot \& Serville, 1843", In B. Aukema, C. Rieger, (Editors). Catalogue of Heteroptera of the Palearctic Region, The Netherlands, 245-258, (2001).

[4] Kristenova, M., Exnerova, A., Štys, P., "Seed preferences of Pyrrhocoris apterus (Heteroptera: Pyrrhocoridae): Are there specialized trophic populations?", European Journal of Entomology, 108(4): 581-586, (2011).

[5] Hinton, H.E., Biology of Insect Eggs, Vols I-III, Oxford, (1981).

[6] Salkeld, E.H., "A catalogue of the eggs of some Canadian Geometridae (Lepidoptera), with comments", Memoirs of the Entomological Society of Canada, 126: 1-271, (1983).

[7] Salkeld, E.H., "A catalogue of the eggs of some Canadian Noctuidae (Lepidoptera)", Memoirs of the Entomological Society of Canada, 127: 1-167, (1984).

[8] Margaritis, L.H., "Structure and Physiology of the Eggshell", G.A. Kerkut, L.I. Gilbert (Editors). Comprehensive Insect Physiology, Pergamon Press, Oxford, 153-230, (1985).

[9] Grigorov, P., "Electron-microscopic study of the egg's chorion [sic] in species of the genus Eurygaster Lap. (Heteroptera, Scutelleridae)", Rasteniev'dni Nauki, 25: 94-99, (1988).

[10] Suludere Z., Candan S., Kalender Y., "Chorionic sculpturing in eggs of six species of Eurydema (Heteroptera, Pentatomidae) A scanning electron microscope investigation", Journal of the Entomological Research Society, (2): 27-56, (1999).

[11] Bundy, C.S., McPherson, R.M., "Morphological examination of stink bug (Heteroptera: Pentatomidae) eggs on cotton and soybeans, with a key to genera", Annals of the Entomological Society of America, 93(3): 616-624, (2000). 
[12] Bundy, C.S., McPherson, J.E., "Morphological examination of the egg of Mecidea major (Heteroptera: Pentatomidae)", Southwestern Entomologist, 30(1): 41-45, (2005).

[13] Baker, G.T., Chandrapatya, A., "Morphology of the chorion of Diapheromera femorata (Phasmida: Heteronemiidae)", Proceedings of the Entomological Society of Washington, 103 (4): 849-853, (2001).

[14] Wolf, K.W., Reid, W., "Egg morphology and hatching in Mormidea pictiventris (Hemiptera: Pentatomidae)", Canadian Journal of Zoology, 79: 726-736, (2001).

[15] Wolf, W.K., Reid, W., "Post depositional dynamics of eggs of Podisus sagitta (Hemiptera: Pentatomidae: Asopinae). A light and scanning electron microscopy study", Journal of the Entomological Research Society, 6: 1-11, (2004).

[16] Ubero-Pascal, N., Fortuño, J.M., Puig, M.A., "New application of air-drying techniques for studying Ephemeroptera and Plecoptera eggs by scanning electron microscopy", Microscopy Research and Technique, 68: 264-271, (2005).

[17] Candan, S., Suludere, Z., Erbey, M., "Morphology of eggs and spermatheca of Odontotarsus purpureolineatus (Heteroptera, Scutelleridae)", Biologia, 62(6): 763-769, (2007).

[18] Candan, S., Suludere, Z., Güllü, M., "Description of spermatheca and eggs of Eurygaster austriaca (Schrank, 1778) (Heteroptera: Scutelleridae), based on optical and scanning electron microscopy", Turkish Journal of Zoology, 35(5): 653-662, (2011).

[19] Perez-Goodwyn, P.J., Ohba, S., Schnack, J. A., "Chorion morphology of the eggs of Lethocerus delpontei, Kirkaldyia deyrolli, and Horvathinia pelocoroides (Heteroptera: Belostomatidae)", Russian Entomological Journal, 15(2): 151-156, (2006).

[20] Matesco, V.C., Fürstenau, B.B.R.J., Bernardes, J.L., Schwertner, C.F., Grazia, J., "Morphological features of the eggs of Pentatomidae (Hemiptera: Heteroptera)", Zootaxa, 1984(1): 1-30, (2009).

[21] Vilimova, J., Rohanova, M., "The external morphology of eggs of three Rhopalidae species (Hemiptera: Heteroptera) with a review of the eggs of this family", Acta Entomol Musei Natioalis Pragae, 50: 75-95, (2010).

[22] Bianchi, F.M., Matesco, V.C., Campos, L.A., Grazia, J., "External morphology of the egg and the first and fifth instars of Cyrtocoris egeris Packauskas \& Schaefer (Hemiptera: Heteroptera: Pentatomidae: Cyrtocorinae)", Zootaxa, 2991(1): 29-34, (2011).

[23] Sandoval, C.M., Nieves, E., Angulo, V.M., Rosa, J.A., Aldana, E., "Morphology of the eggs of the genus Belminus (Hemiptera: Reduviidae: Triatominae) by optical and scanning electron microscopy", Zootaxa, 2970: 33-40, (2011).

[24] Dimaté, F.A.R., Poderoso, J.C.M., Serrão, J.E., Candan, S., Zanuncio, J.C., "Comparative morphology of eggs of the predators Brontocoris tabidus and Supputius cincticeps (Heteroptera: Pentatomidae)", Annals of the Entomological Society of America, 107(6): 1126$1129,(2014)$. 
[25] Lay, M., Zissler, D., Hartmann, R., "Ultrastructural and functional aspects of the spermatheca of the African Migratory Locust Locusta migratoria migratorioides (Reiche and Fairmaire) (Orthoptera: Acrididae)", International Journal of Insect Morphology and Embryology, 28(4): 349-361, (1999).

[26] Pendergrast J.G., "Studies on the reproductive organs of the Heteroptera with a consideration of their bearing on classification", Transactions of the Entomological Society of London, 109: $1-63,(1957)$.

[27] Dufour, L., "Recherches anatomique et physiologiques sur les Hemipteres", Memoria Press Academy Science, 4: 133-461, (1833).

[28] von Siebold, C. T. "Fernere beobachtungen uber die spermatozoen der wirbellosen tiere. 2. Die spermatozoen der Paludina vivipara", Archiv für Anatomie und Physiologie, 1: 232-255, (1836).

[29] Dupuis, C., "Les génitalia des Hémipt'eres Hétéropt’eres (Génitalia externes des deux sexes; Voies ectodermiques femelles). Revue de la morphologie. Lexique de la nomenclature. Index bibliographique analytique", Mémoires du Muséum National d'Histoire Naturelle, 6: 183-278, (1955).

[30] Scudder, G.G.E., "The female genitalia of the Heteroptera: Morphology and bearing on classification", Transactions of the Entomological Society of London, 111: 405-467, (1959).

[31] Kumar, R., "Morpho-taxonomical studies on the genitalia and salivary glands of some Pentatomoidea", Entomologisk Tidskrift, 83: 44-84, (1962).

[32] McDonald, F.J.D., "The genitalia of North American Pentatomoidea (Hemiptera: Heteroptera)", Quaestiones Entomologicae, 2: 7-150, (1966).

[33] Servadei, A., "Il valore tassonomico delle spermateche degli emitteri eterotteri (Fam. Pentatomidae e Acanthosomatidae)", Atti Della Accademia Nazionale Italiana di Entomologia, 11: 58-86, (1964).

[34] Lee, C.E., Pendergrast, J.G., "The spermathecae of New Zealand Aradidae (Hemiptera: Heteroptera)", Journal of Natural History, 17(1): 113-122, (1983).

[35] Vavrinova, I., "Spermathecae of Central European species of the families Rhopalidae, Alydidae and Coreidae (Heteroptera, Coreoidae)", Acta Musei Silesiae, Scientiae Naturales, 73: 203-215, (1988).

[36] Kim, R.H., Lee, C.E., "Morphological studies on the spermathecae of Korean Podopinae and Asopinae (Heteroptera: Pentatomidae)", Korean Journal of Applied Entomology, 24: 217-223, (1994).

[37] Gschwentner, R., Tadler, A., "Functional anatomy of the spermatheca and its duct in the seed bug Lygaeus simulans (Heteroptera: Lygaeidae)", European Journal of Entomology, 97(3): 305-312, (2000). 
[38] Candan, S., "Spermathecal morphology of Enoplops disciger (Kolenati, 1845) (Heteroptera: Coreidae)", Entomological News, 119(5): 524-530, (2008).

[39] Candan, S., Erbey, M., Özyurt, N., Suludere, Z., "Spermathecae morphology in four species of Eurydema Laporte, 1833 (Heteroptera: Pentatomidae) from Turkey: a scanning electron microscope study”, Journal of Entomology and Zoology Studies, 2(3): 206-213, (2014).

[40] Candan, S., Yilmaz, F.S., Suludere, Z., Erbey, M., "Morphology of spermathecae of some pentatomids (Hemiptera: Heteroptera: Pentatomidae) from Turkey", Zootaxa, 3937(3): 500516, (2015).

[41] Kocorek A., Danielczok-Demska, T., "Comparative morphology of the spermatheca within the family Dinidoridae (Hemiptera: Heteroptera)", European Journal of Entomology, 99: 9198, (2002).

[42] Pluot-Sigwalt, D., Lis, J.A. "Morphology of the spermatheca in the Cydnidae (Hemiptera: Heteroptera): Bearing of its diversity on classification and phylogeny", European Journal of Entomology, 105(2): 279, (2008).

[43] Pluot-Sigwalt, D., Péricart, J., "The spermatheca of the Dipsocoridae with special reference to the strange "loculus capsulae" in Harpago species (Heteroptera, Dipsocoromorpha)", In Annales de la Société entomologique de France, 39(2): 129-138, (2003).

[44] Chiang, R.G. "Functional anatomy of the vagina muscles in the adult western conifer seed bug, Leptoglossus occidentalis (Heteroptera: Coreidae), and its implication for the egg laying behaviour in insects", Arthropod Structure \& Development, 39(4): 261-267, (2010).

[45] De Sá, V.G.M., Zanuncio, J.C., Soares, M.A., Rosa, C.S., Serrao, J.E., "Morphology and postdepositional dynamics of eggs of the predator Podisus distinctus (Stål) (Heteroptera: Pentatomidae: Asopinae", Zootaxa, 3641(3): 282-288, (2013).

[46] Stacconi, M.V.R., Romani, R., "Ultrastructural and functional aspects of the spermatheca in the American harlequin bug, Murgantia histrionica (Hemiptera: Pentatomidae)", Neotropical Entomology, 40(2): 222-230, (2011).

[47] Souza, E.A., Lisboa, L.C.O., Araújo, V.A., Serrão, J.E. "Morphology of the spermathecae of Leptoglossus zonatus (Heteroptera: Coreidae)", Annals of the Entomological Society of America, 109(1): 106-111, (2016).

[48] Pascini, T.V., Martins, G.F., "The insect spermatheca: an overview”, Zoology, 121: 56-71, (2017).

[49] Pluot-Sigwalt, D., Moulet, P., "The coreine spermatheca: morphological structure and terminology (Heteroptera: Coreidae: Coreinae)”, Dugesiana, 24(2): 177-182, (2017).

[50] Candan, S., Suludere, Z., Durak, D., "Ultrastructure of the eggs chorion of Ceraleptus obtusus (Brullé, 1839) (Heteroptera: Coreidae)", Ohio Journal of Science, 105: 138-141, (2005).

[51] Brugnera, R., Grazia, J., "External morphology of immature of Tynacantha marginata Dallas, 1851 (Hemiptera, Heteroptera, Pentatomidae)", Zootaxa, 4378(1): 121-128, (2018). 